\title{
JPAS-004 高齢化社会において心理学はどのような貢献が可能か
}

\author{
企画代表者、司会者：長田 久雄（桜美林大学） \\ 企画者、司会者:箱田 裕司 (京都女子大学) \\ 話題提供者：松田修 (東京学芸大学) \\ 話題提供者 : 雚牟田洋美 (首都大学東京) \\ 話題提供者：原田 悦子 (筑波大学) \\ 話題提供者：原田 和弘（国立長寿医療研究センター） \\ 指定討論者 : 今田寛 (関西学院大学名誉教授) \\ 指定討論者：御領 謙 (千葉大学名誉教授)
}

日本は，全人口に占める65歳以上の高齢者の割合が $25 \%$ 超えた。また， 100 歳以上の長寿者も 5 万人 以上となり, 本格的な高齢長寿社会を迎えた。このような背景の中で, 高齢者, 高齢社会, 加齢・老化 に関する諸課題は広範囲に及び，現在，その解明や解決は極めて重要かつ急務となっている。高齢者の 認知機能や感情の特徵、熟達や英知、高齢者の就業や運転、認知症や閉じこもり, うつ状態や自殺, 老 化による心身の機能や日常生活機能の低下やそれに対する予防や対応など，基礎から応用・臨床に至る 様々な心理学の領域に関連するテーマも多い。本シンポジウムでは, 認知症や閉じこもり, 心身機能の 低下や高齢者の日常生活の不自由さなどに対して, 心理学にはどのような専門的貢献が可能かというこ とを，とくに心理的支援という観点を中心にして話題提供を行い，今後一層の進行が不可避である高齢 長寿社会に，心理学の果たす役割を考える機会としたい。 